\title{
Antioxidant and Cytotoxic Activitiy of Limonia acidissima L.
}

\section{Sadia Shermin, Fahima Aktar, Monira Ahsan and Choudhury M. Hasan}

\author{
${ }^{1}$ Department of Pharmaceutical Chemistry, Faculty of Pharmacy, University of Dhaka, \\ Dhaka-1000, Bangladesh
}

The crude methanol extract of the stem bark of Limonia acidissima L. and its different organic soluble partitionates were screened for cytotoxic and antioxidant activities. The brine shrimp lethality bioassay was used to evaluate the cytotoxicity. The petroleum ether soluble fraction (PESF) of the methanolic extract exhibited strong cytotoxic activity $\left(\mathrm{LC}_{50}=2.0779 \mu \mathrm{g} / \mathrm{ml}\right)$. On the other hands chloroform soluble fraction of the methanolic extract showed the highest free radical scavenging activity with $\mathrm{IC}_{50}$ value $18.80 \mu \mathrm{g} / \mathrm{ml}$.

The plant L. acidissima (Family- Rutaceae) is known as Kath bael in Bangla and is a common plant of Bangladesh. Its leaves, bark and then fruits have medicinal values and used as traditional medicines for centuries due to their antimicrobial, ${ }^{1}$ antifungal, ${ }^{2,3}$ astringent, anti-inflammatory ${ }^{4}$ and insulin secretogouge ${ }^{5}$ activities. In the south Asian countries like Mayanmar, Thailand etc., the bark of the tree is used as a popular natural cosmetic. ${ }^{6}$ Different parts of the plant are also used as insecticides, anti-rodent in animal husbandry. ${ }^{7-9}$

Previous phytochemical investigations led to the isolation of coumarins, phytostrols, tyramine derivatives, phenolic acids, limonoids, flavonones etc from $L$. acidissima. $^{10-18}$ Since this plant has various medicinal properties so the present study was undertaken to evaluate the antioxidant and cytotoxic activities of methanolic extract of bark of $L$. acidissima systematically.

Correspondence to: Choudhury Mahmood Hasan Contact no.: +8801819253698

E-mail: cmhasan@gmail.com

Dhaka Univ. J. Pharm. Sci. 11(1): 75-77, 2012 (June)
Plant sample (stem bark) of L. acidissima was collected from Pabna in November, 2008. A voucher specimen (DACB - 35734) for this collection has been deposited in Bangladesh National Herbarium, Mirpur, Dhaka-1216. The samples were cut into small pieces and sun dried for 7 days followed by oven drying for 24 hours at $40^{\circ} \mathrm{C}$. The powdered material (300 g) was then soaked in 1.50 liter of methanol in a large conical flask for 7 days with occasional shaking and stirring. The whole mixture was filtered off through a cotton plug followed by Whatman filter paper no.1 and the filtrate was concentrated using a Buchi rotary evaporator. The crude extract was then fractioned by using the modified Kupchan partitioning protocol. ${ }^{19}$

DMSO solutions of all the extractives were applied against Artemia salina in a one-day in vitro assay. ${ }^{20}$ For the experiment, $4 \mathrm{mg}$ of each of the fractions was dissolved in DMSO and solutions of varying concentrations such as $400,200,100,50,25$, $12.50,6.25,3.125,1.563,0.78125 \mu \mathrm{g} / \mathrm{ml}$ were obtained by serial dilution technique. Vincristine sulphate and DMSO were used as the positive and negative control, respectively. Table 1 shows the results of the brine shrimp lethality bioassay after 24 hr exposure of the shrimps to the test samples.

The antioxidant (free radical scavenging) activity of the partitionates on the stable radical 1,1-diphenyl2-picrylhydrazyl (DPPH) was determined by the method developed by Brand-Williams et al. ${ }^{21,22}$ Here, $2.0 \mathrm{mg}$ of each of the test sample was dissolved in methanol and solution of varying concentrations such as 500, 250, 125, 62.50, 31.25, 15.62, 7.8125, 3.91, 1.95 and $0.98 \mu \mathrm{g} / \mathrm{ml}$ were obtained by serial dilution technique. Then $2 \mathrm{ml}$ of each of the test 
sample was mixed with $3 \mathrm{ml}$ of a DPPH-methanol solution $(20 \mu \mathrm{g} / \mathrm{ml})$ and was allowed to stand for 20 minutes for the reaction to occur. The absorbance was determined at $517 \mathrm{~nm}$ and from these values, the corresponding percentage of inhibitions were calculated by using the following equation:

$\%$ inhibition $=\left[1-\left(\mathrm{ABS}_{\text {sample }} / \mathrm{ABS}_{\text {control }}\right)\right] \times 100$

Then \% inhibitions were plotted against respective concentrations used and from the graph the IC $_{50}$ was calculated using ascorbic acid, as the positive control. Three replicates of each sample were used for statistical analysis and the values are reported as mean $\pm \mathrm{SD}$.

The present study was undertaken to evaluate the cytotoxic and antioxidant activities of the organic soluble portion of a methanol extract of L. acidissima and the results have been summarized in Table 1 . In the brine shrimp lethality bioassay, the pet ether soluble partitionate (PE) showed strong cytotoxic activity with $\mathrm{LC}_{50}$ value of $2.0779 \mu \mathrm{g} / \mathrm{ml}$. The chloroform soluble partitionate (CL) exhibited significant lethality having $\mathrm{LC}_{50}$ value of $6.8975 \mu \mathrm{g} /$ $\mathrm{ml}$, while the crude metanolic extract (ME) demonstrated moderate activity against shrimp nauplii with the $\mathrm{LC}_{50}$ of $20.6226 \mu \mathrm{g} / \mathrm{ml}$ (Table 1 \& Figure 1). In case of screening for antioxidant activity (Table 1 \& Figure 2), the chloroform soluble fraction (CL) of crude methanolic extract showed the highest free radical scavenging activity with $\mathrm{IC}_{50}$ value 18.8 $\mu \mathrm{g} / \mathrm{ml}$. At the same time the pet ether soluble fraction (PE) also exhibited strong antioxidant potential having $\mathrm{IC}_{50}$ value of $37.64 \mu \mathrm{g} / \mathrm{ml}$.

Table 1. Free radical scavenging and cytotoxic activity of different partitionates of $L$. acidissima

\begin{tabular}{ccc}
\hline Sample & $\begin{array}{c}\text { Antioxidant activity } \\
\left(\mathrm{IC}_{50} \mu \mathrm{g} / \mathrm{ml}\right)\end{array}$ & $\begin{array}{c}\text { Cytotoxic activity } \\
\left(\mathrm{LC}_{50} \mu \mathrm{g} / \mathrm{ml}\right)\end{array}$ \\
\hline VS & - & $0.451 \pm 1.25$ \\
$\mathrm{BHT}$ & $17.69 \pm 0.89$ & - \\
$\mathrm{ME}$ & $292.16 \pm 1.07$ & $20.62 \pm 0.76$ \\
$\mathrm{PE}$ & $37.64 \pm 1.19$ & $2.077 \pm 0.42$ \\
$\mathrm{CL}$ & $18.8 \pm 0.78$ & $6.89 \pm 0.58$ \\
\hline
\end{tabular}

Where, VS $=$ Vincristine sulphate, BHT = Butylated Hydroxy Toluene, ME = Methanolic Extract of Bark of Plant, PE $=$ Pet Ether Soluble Fraction, $\mathrm{CL}=$ Chloroform Soluble Fraction.

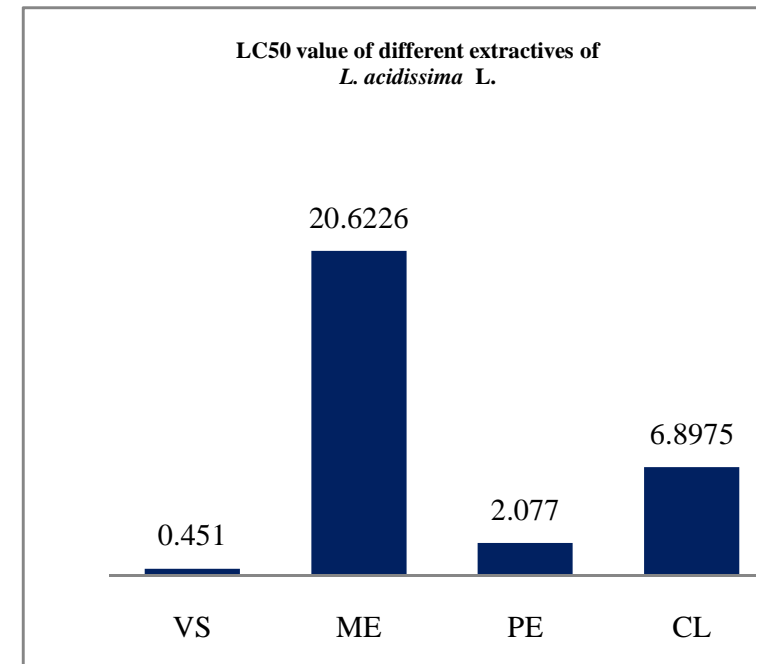

Figure 1. LC 50 values of the different extractives of $L$. acidissim

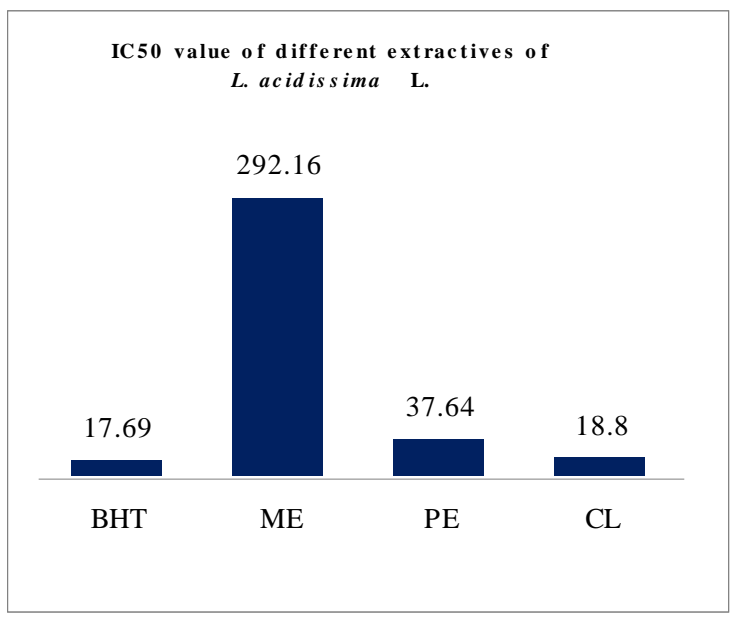

Figure 2. $\mathrm{IC}_{50}$ values of the different extractives of $L$. acidissima

\section{REFERENCES}

1. Bandara, B.M.R., Hewage, C.M., Jayamanne, D.H.L.W., Karunaratne, V., Asikaram, N. K. B., Bandara, K.A.N.P. and Wijesundara, D.S.A. 1990. Biological activity of some steam distillates from leaves of ten species of rutaceous plants. $J$. Natn. Sci. Coun. Sri Lanka. 18, 71-77.

2. Khewkhom, N., Greger, H. and Shangchote, S. 2008. Antimicrobial activity of 16 plant extracts of the Rutaceae family against phytopathogenic fungi. Agricultural Sci. J. 39, 119-123.

3. Adikaram , N.K.B., Abhayawardhane, Y., Gunatilaka, A. A.L., Bandara, B.M.R. and Wijeratne, E.M.K. 2007. Antifungal activity, acid and sugar content in the wood apple (Limonia acidissima) and their relation to fungal development. Plant Pathology 38, 258-265. 


\section{Antioxidant and Cytotoxic Activitiy of Limonia acidissima77}

4. Kim K.H., Ha S.K., Kim S.Y., Kim S.H. and Lee K.R. 2009. Limodissimin A: A New dimeric coumarin from Limonia acidissima. Bull. Korean Chem. Soc. 30, 2135-2137.

5. Gupta, R., Johri, S. and Saxena, A.M. 2009. Effect of ethanolic extract of Feronia elephantum Correa fruits on blood glucose level in normal and streptozotocin-induced diabetic rats. Natural Product Radiance 8, 32-36.

6. Non-wood news, Thanakha, 2007. Myanmar's Natural Cosmetic, 14, 6.

7. Honey Bee, Livestock and Animal Husbandry, 1993. 4, 17.

8. Honey Bee, creative farmers of eastern India : A learning post in district Faizabad, 1993. 4, 6-6.

9. Bandara, B.M. R., Gunatilake, A.A.L., Sotheeswaran, S. and Wijeratne, E.M.K. and Ranasinghe M.A.S.K. 1989. Insecticidal properties and an active constituents of Limonia acidissima L., J. Natn. Sci. Coun. Sri Lanka. 17, 237-239.

10. Intekhab, J., Siddiqui, N.U. and Aslam, M. 2008. Flavone glycoside from the roots of Feronia limonia. Oriental Journal of Chemistry. 24

11. Mondal, S.K., Ray, B., Thibault, J.F. and Ghosal, P.K. 2002. Cell-wall polysaccharides from the fruits of Limonia acidissima: isolation, purification and chemical investigation, Carbohydrate Polymers. 48, 209-212.

12. Rahman, M.M. and Gray A.I. 2002. Antimicrobial constituents from the stem bark of Feronia limonia. Phytochemistry. 59, 173-77.

13. Rahuman, A.A., Gopalakrishnan, G., Ghouse, B.S., Arumugam, S. and Himalayan, B. 2000. Effect of Feronia limonia on mosquito larvae. Fitoterapia, 71, 553-555.
14. Saima Y., Das, A.K., Sarkar, K.K., Sen, A.K. and Sur, P. 2000. An antitumor pectic polysaccharide from Feronia limonia. Int. J. Biol. Macromolecules, 27, 333-335.

15. Ghosh, P., Sil, P., Majumdar, S.G. and Thakur, S. 1982. A coumarin from Limonia acidissima. Phytochemistry 21, 240241.

16. Das, S. and Thakur, S.1989. Constituent acids of Limonia acidissima leaf cutin. Phytochemistry. 28, 509-511.

17. Agrawal, A., Siddiqui I.R. and Singh, J. 1989. Coumarins from the roots of Feronia limonia. Phytochemistry 28, 12291231.

18. Ghosh, P., Ghosh, M.K., Thakur, S., Dan, J., Akihisa, T., Tamura, T. and Kimura, Y. 1994. Dihydroxy acidissiminol and acidissiminol epoxide, two tyramine derivatives from Limonia acidissima, Phytochemistry 37, 757-760.

19. Vanwagenen, B.C., Larsen, R., Cardellina, J.H. Randazzo, D., Lidert, Z.C. and Swithenbank, C. 1993. Ulosantoin, a potent insecticide from the sponge Ulosa ructzleri. J. Org. Chem. 58, 335-337.

20. Meyer B.N., Ferrigni N.R., Putnam J.E., Jacobsen J.B., Nicholsand D.E. and Mclaughlin J.L. 1982. Brine shrimp; a convenient general bioassay for active plant constituents. Planta. Med. 45, 31-34.

21. Choi, H.Y., Jhun, E.J., Lim, B.O., Chung, I.M., Kyung, S.H. and Park, D.K. 2000. Application of flow injectionchemilumineacence to the study of radical scavenging activity in plants. Phytother Res. 14, 250-253.

22. Desmarchelier C., Repetto, M., Coussio, J., Liesuy, S. and Ciccia, G. 1997. Antioxidant and prooxidant activities in aqueous extracts of Argentine plants. Int. J. Pharmacog. 35, 116-120. 